\title{
FBLN2 wt Allele
}

National Cancer Institute

\section{Source}

National Cancer Institute. FBLN2 wt Allele. NCI Thesaurus. Code C143131.

Human FBLN2 wild-type allele is located in the vicinity of 3p25.1 and is approximately 89 $\mathrm{kb}$ in length. This allele, which encodes fibulin- 2 protein, is involved in the structure of the extracellular matrix. 